FACTA UNIVERSITATIS

Series: Economics and Organization Vol. 16, N ${ }^{\mathrm{o}} 3,2019$, pp. 255 - 268

https://doi.org/10.22190/FUEO1903255T

Review Paper

\title{
THE IMPACT OF AUTOMATED TRADING SYSTEMS ON FINANCIAL MARKET STABILITY
}

\author{
UDC 339:336.76
}

\author{
Violeta Todorović, Aleksandra Pešterac, Nenad Tomić \\ University of Kragujevac, Faculty of Economics, Kragujevac, Serbia
}

\begin{abstract}
The way in which financial markets operate has substantially been changed by the development of information technology. Automation of trading systems in financial markets represents the last phase of depersonalizing activities previously done by traders. Automated trading development enabled computers to determine the moment and the way of executing sales orders. Computers still do not make autonomous decisions regarding the choice of instruments to be traded or trading criteria. They implement the strategy a trader has decided on, choosing a favorable moment. This reduces the impact of human emotions on decision making and enables overcoming possible problems which arise due to neglect or lack of concentration. High-frequency trading enables the execution of algorithmic operations at a high speed. The main goal of the paper is to determine advantages and dangers produced by automated stock trading.
\end{abstract}

Key words: automated trading system, financial markets, high-frequency trading

JEL Classification: G10, O33

\section{INTRODUCTION}

The rapid development of computer technology and the importance of its application in contemporary business operations have positioned financial sector as one of the leading in applying modern technology. In order to increase efficiency and ensure continuity in conducting financial transactions, financial markets have succeeded in making the best use of technological development. Unlike previous ways of performing stock trading and visible trade that used to happen on conventional stock exchange markets with the

Received February 20, 2019 / Revised May 20, 2019 / Accepted May 29, 2019

Corresponding author: Aleksandra Pešterac

University of Kragujevac, Faculty of Economics, Liceja Kneževnine Srbije 3, 34000 Kragujevac, Serbia

E-mail: apesterac@kg.ac.rs 
physical presence of traders, a series of consecutive purchasing or sale operations on stock exchanges is carried out today via electronic systems. Further development of these systems has contributed to the creation of electronic networks, thus providing continuity in the work at the global level through the improvement of information flows. Human activity is replaced by automated trading systems which use predetermined parameters to make autonomous decisions on the execution of trading.

In the past decade, the participation of automated trading systems in the total trading volume tripled. Over time, these systems have become an indispensable part of the markets where sophisticated technology is used to manage all levels of the value chain. Given the increasing importance of automated trading systems for financial markets, the paper seeks to provide updated basic information about these systems by precisely defining terms, strategies and trading software, as well as by presenting empirical researches. The subject of the paper is the influence of automated trading systems use on trading process. The main goal of the paper is to determine advantages and risks caused by automated stock trading.

The first part of the paper analyses the long-term trend of reducing the share of manual work in financial markets which resulted in the development of systems that autonomously enter and execute orders. The second part presents the basic characteristics of automated trading systems. The focus of the third part of the paper will be on trading strategies and software methods. The last part will include the analysis of empirical data and earlier research on the effects of automated stock trading.

\section{TRADE DEPERSONALIZATION IN FinANCIAL MARKETS}

The beginning of stock exchanges was marked by highly intense manual work of traders. Trade was carried out at trading venues through direct communication of traders, and demanded direct handling of financial instruments. For many years, regulations were the only improved aspect, while trading mechanisms remained unchanged. The main shortcomings of the conventional form of trading on the floor are low level of transparency, need for the participation of numerous staff, paperwork overload and slow supply-demand matching (Stoll, 2006, pp. 167). Therefore, as a rule, the innovation of trading was aimed at increasing the speed and quality of the information flow and abuse prevention.

Communication between traders used to be done directly at a trading venue. Requiring permanent physical presence of traders, direct communication was considered to be inadequate. Traders often neither had the opportunity to check the information they arrived at, nor could they do the analysis and/or calculation of the current situation. Instead, they had to make decision as soon as possible so as not to miss the opportunity. The absence of a timely reaction could cause huge losses or lead to a loss of potential earnings. Such circumstances created good opportunities for fraud caused by communicating incomplete or false information. The introduction of the phone as a channel of communication provided traders with the opportunity to retreat into their own offices. The collection and verification of information was facilitated, which created the ability to perform an analytical forecast during the process of trade. However, an obvious limitation of the telephone use was a bilateral communication with other participants. If a 
trader wanted to be the first to contact another trader by telephone, he/she would have to find the right order among the offered ones. The first computers in financial markets provided traders with the ability to instantly obtain information on the movement of financial instrument prices and order matching. In this way, investors were given the convenience of quickly selecting the most favorable financial transaction both at the national and international financial markets (Jakšić, 2016, pp. 51). Communication became multilateral, since it enabled a trader to communicate simultaneously with all participants.

Informing is one of the key functions for ensuring efficient stock trading. Brokerage houses must have a quick and easy access to all relevant information concerning the quality of financial instruments, price movements and trading volume. Since stock exchange is not primarily concerned with information flow but rather presents a system of organized and safe trading, the aforementioned can be taken as a progress in stock exchange operations, as far as its function is communicating information (Dugalić \& Štimac, 2011, pp. 122). In some earlier times, all information had to be retrieved, sorted and processed manually by employees. Computer systems have enabled the automation of this process, through accelerated information gathering, separating relevant from irrelevant information and its processing. By developing FIX protocol in 1992, a standardized basis for pre-trade communication and trade execution was created.

Due to the processes of immobilization and decentralization, shares have ceased to be physically transferred in a trading process. Immobilization of shares refers to their keeping in one place trusted by all participants - a central depository. Shares are no longer transferred physically from a seller to a buyer during the trade; instead, the bookkeeping transfer of ownership is made. In this way, trading costs are reduced, the possibility of creating liquidity and credit risks is diminished, and the time required for the completion of the entire process is shortened. In addition, immobilization prevented the risk of losing or stealing financial instruments (Kanzaki, 1981, pp. 115). The following step in handling stock is dematerialization during which immobilized instruments completely lose their physical form. Shares lose their physical form and become electronic records on the owner's account at the central depository. Stock trading started to take the form of mechanisms of cashless transactions, where, instead of regulating debtor-creditor relations, ownership relations are regulated (Vuksanović, 2009, p. 225).

The final outcome was the reduction of the needed number of employees in stock companies, faster distribution of information and easier order matching. A number of computer softwares were developed for the purpose of analyzing the performed transactions and predicting future trends. However, regardless of the logistic support provided by the use of ICT, the decisions on trading were still made by traders. Innovation of the activities that have played a logistic role in the trading process has created the conditions for changing the approach to the process of trading. The possibility of a very fast distribution of information and its incorporation into predictions put once again the speed of reaction into the focus of the problem. Traders realized that, if properly programmed, computer systems, being deprived of deconcentration and hesitation, were able to eliminate the problem of slow reaction. 


\section{AUTOMATED TRADING SYSTEMS}

Managing trading orders without direct human intervention has become a daily routine in global financial markets. The roles of traders have been taken over by computer algorithms, which automatically make decisions about offers, send orders and manage them (Kaya, 2016). Having noted a favorable opportunity at the market, automated trading systems supported by appropriate software packages independently carry out transactions of buying and selling a certain currency pair, shares or commodities. Despite the positive effects attributed to them, Venkataraman (2001) maintains that it is impossible to completely replace some of the benefits of human intervention in trade market. He emphasizes that the choice of a trading mechanism should involve the creation of a compromise solution between higher operating costs and potentially better order execution in the presence of a floor broker.

The process of trading in the financial market has been altered forever by the use of computer technology. Computers can now independently carry out all the activities or give signals for buying or selling, while the decisions are made by the trader. There are differences between electronic, algorithmic and high-frequency trading. Within electronic trading, a person makes decisions about the purchase, but he/she does not send the orders personally or by telephone, but via the electronic system. Algorithmic trading involves computer execution of sales transactions, in which computers use the parameters of a predefined algorithm to make a decision on a trading instrument, moment and quantity (Sajter, 2013, pp. 322). In algorithmic trading, computer algorithms not only distribute orders, but also make decisions about the moment and amount of their execution (Aldridge, 2013, pp. 10-11).

One of the first attempts to define high-frequency trading in Europe was done by the European Securities Markets Authority. This organization points out that high-frequency trading involves trading in a very short period of time with low price differences where the dominant focus is on highly liquid instruments, and the ultimate goal is to close all open positions at the end of a business day (Gregoriou, 2015, pp. 159). The main advantage of high-frequency trading is that they can spot price discrepancy and execute a trade much faster than traders with limited cognitive abilities (Das \& Kadapakkam, 2018, pp. 4). The term high-frequency trading does not have a generally accepted or legal definition. However, an optional definition of high-frequency trading was offered at the 2012 meeting of the Technical Advisory Committee for Automated and High Frequency Trading (CFTC) (Miller \& Shorter, 2016, pp. 1):

- decision-making algorithm (initiating, generating, directing or executing orders) for each individual transaction, with no human intervention;

- low latency technology, designed to minimize response times and make trading closer;

- technology that establishes a fast connection, i.e. communication with the market in order to enter orders and transfer a large number of messages about orders, quotes or cancellation of order execution.

Algorithmic trading can comprise trading in shares, bonds, currencies, and goods (Kissell, 2014, pp. 1). With the help of advanced and complex mathematical models for making decisions in automated systems, strict rules determine the optimal time for an order execution, which can be changed or cancelled during realization, causing the least 
possible impact on the price of shares (Dubey, Chauhan, \& Syamala, 2017, pp. 2). Apart from being more efficient and capable of performing complex calculations and processing a large amount of information and data, computers are also extremely suitable for rapid reaction to changes in market conditions. This is a necessary feature for real-time trading in a turbulent environment which characterizes today's financial markets. High investments in the construction of computer networks and appropriate data transfer technologies have made it possible to measure the duration of order execution in milliseconds (Zook \& Grote, 2016, pp. 4).

The last 20 years recorded a remarkable growth achieved by automated trading systems, which is evidenced by the fact that a half of the overall trading in global stock markets is done through these systems (Zook \& Grote, 2016, pp. 1). Kirilenko and Lo (2013) point to three key changes in financial market operations that opened the door to the rapid development of automated trading systems. The first change relates to financial system structure, which has become increasingly complex over time. Globalization and economic growth have led to an increase in the number of market participants, different forms of financial transactions, changes in the level and distribution of risks, etc. With an ever increasing complexity of the financial system, the development of computer technologies in this field was considered necessary. Quantitative modeling of financial markets has created a strong theoretical basis underlying automated trading. The third change relates to the already mentioned integration of computer technology into financial system operations and its impact on the collection and organization of data and communication.

\section{Automatic Trading StRATEGIES AND SOFTWARES}

Financial market traders have different goals and priorities, different amounts of available assets, and different risk tolerance. Due to all this, their trading strategies also vary. A trading strategy is a predefined set of rules that are strictly applied during trading. The basic set of rules should precisely describe the conditions to be met in order to open the position of buying or selling, the way of determining the amount traded and the conditions under which positions are closed (Ilić, 2010 a). Based on the observed parameters, an automatic trading system checks whether the conditions for opening or closing the position are fulfilled and, if so, sends orders for trading. The three key components of each trading strategy are: entering and leaving trading, risk management and positioning (Ilić \& Brtka, 2011).

Trading strategies depend on the ability to recognize the opportunity for trading and the speed of responding to an order (Lakić, 2014, pp. 8). The formation of a trading strategy consists of the following steps: formulation, trading rules specification and software package development, preliminary testing (simulation with historical data), parameter optimization (selection of optimal trading strategy, maximum profit, lowest risk, etc.), performance appraisal, implementation of a strategy in realistic conditions, monitoring trading performance (comparison of real results with simulation results), evaluation of strategies and recommendations for further improvements (Ilić \& Brtka, 2011).

A key part of each trading strategy is to determine favorable moments for the start and end of trading. If trading is activated too early or too late, losses could be made, or in a 
better case, less profit could be achieved than in a situation where trading would be activated at the optimal moment (Ilić, 2010 b). The strategy for opening a trading consists of a trend-following strategy, which helps to open a trading in the direction of market price movements and counter-trend strategy, which opens a trading when direction changes are expected, i.e. trading opens in the opposite direction from the current trend of market prices. Trend-following strategy is based on making decisions about buying or selling solely by observing market trend (Fong, Si, \& Tai, 2012, pp. 11378). The trend is determined at the very beginning of a workday, where further trade during the day automatically proceeds according to a predetermined strategy, regardless of whether there are changes in market trends.

Unlike the input strategy, the output strategy determines the moment when the positions should be closed. A position closing could be aimed at making a profit, or at protecting traders from excessive losses when a price moves in an opposite direction from the expected one. The reasons for closing positions can be situations when prices reach a certain level, if the desired result of a combination of selected technical indicators is reached, or if the level of profit is not reached after a certain period of time (Ilić, $2010 \mathrm{~b}$ ). In addition, algorithms can also be used for speculative purposes, i.e. in situations of taking over the market risk in order to achieve greater profit. These algorithms are mainly based on momentum strategy, relative value strategy and microstructure strategy (Lakić, 2014, pp. 11). In their papers, the authors (MacKenzie, Beunza, Millo, \& Pardo-Guerra, 2012; Zook \& Grote, 2016) name numerous high-frequency trading strategies, including market maker strategies, as well as different arbitrage strategies - statistical arbitrage, cross-market arbitrage, etc.

The optimization of parameters implemented in a trading strategy is undertaken in order to increase profit and reduce risk. When optimizing an input automated trading strategy, it is necessary to determine favorable parameters of technical indicators for increasing profitable trading percentage, while the optimization of an output strategy regulates the level of profit or loss in individual trading and attempts to find the ratio of parameters for achieving the best results (Ilić \& Brtka, 2011). Different trading strategies also have different risk levels, so even the most efficient trading strategies have a certain percentage of loss. Risk management means maintaining the risk within the expected limits which are acceptable in relation to the balance on the account. The main objective of risk management is to limit losses, in a way that there is always a sufficient amount of funds to continue trading, even after a series of trades that ended with a loss (Ilić, 2010a).

High-frequency traders can be classified depending on the trading strategy they implement. The use of aggressive trading strategies is associated with traders who primarily trade by placing market orders, while, on the other hand, the implementation of trade through the limit order indicates traders who opt for passive trading strategies (Lakić, 2014, pp. 15). Traders use aggressive strategies to retain their position, while their trading is focused on tracking the latest price trend (they buy when prices rise and sell when prices fall). Passive strategies are applied by traders who often change their positions in a short period of time (sales are followed by purchases, and vice versa).

The relationship between human participants who designed trading strategies and computers which executed trading orders deepened and evolved into software trading systems (Zook \& Grote, 2016, pp. 5). The handling of trading orders is automated with the help of a software with implemented trading strategies. The development of 
automated trading software begins with a trading plan, i.e. it is necessary to formulate how the trading strategy should function and what is expected from such a strategy. Parameters having been optimized and satisfactory results confirmed by detailed testing, the systems for automatic trading, i.e. softwares and their strategies can be used in practical trading. This procedure is shown in Figure 1.

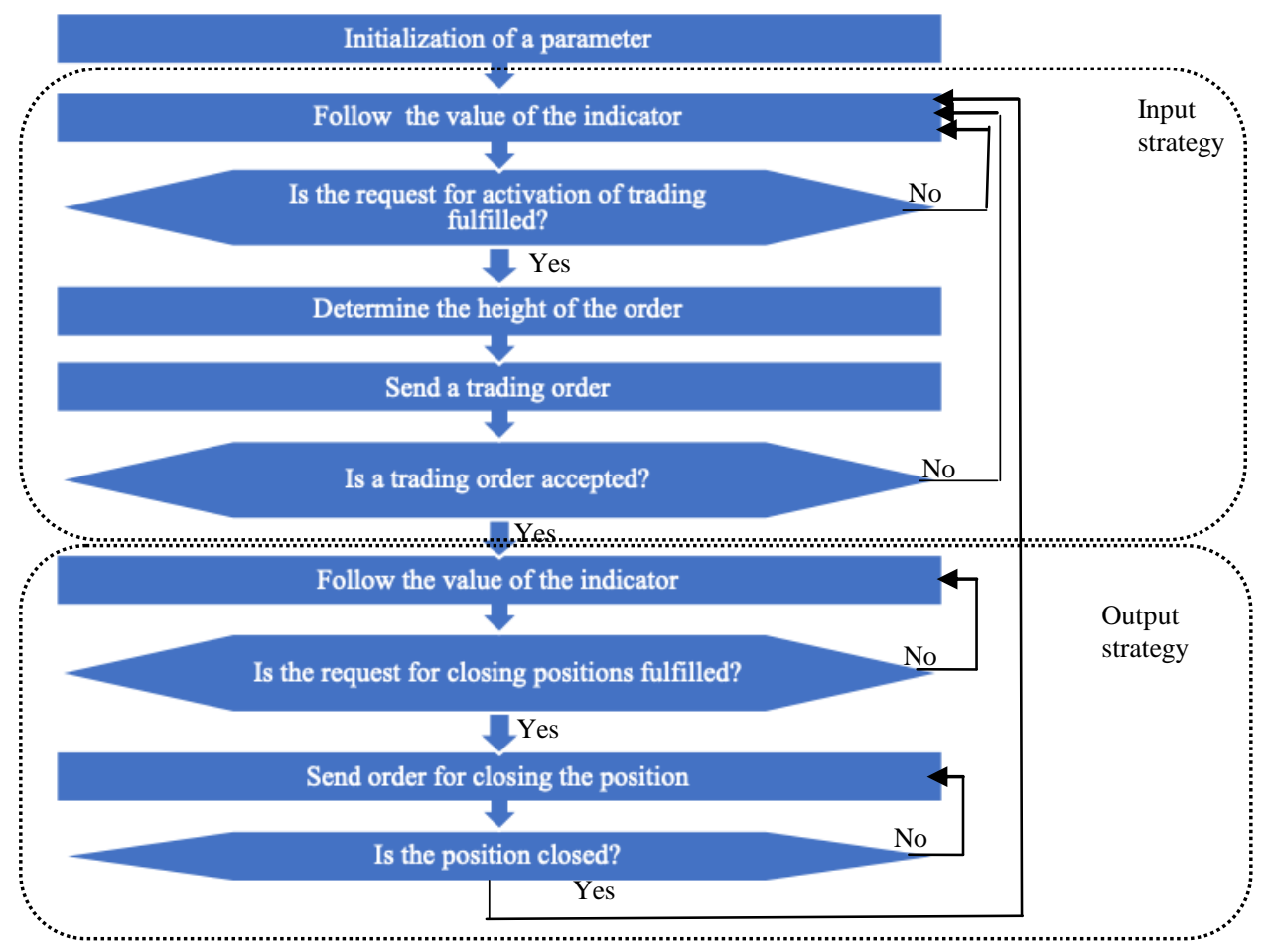

Fig. 1 The structure of the real-time automated trading software Source: Ilic, V. (2010 b). The structure of software for automated trading on foreign exchange market.

Automated trading softwares allow one to track a large number of parameters and at the same time make it easy to decide in real time. They can fully take control of trading activities (opening and closing positions and determining the amount of deposits). At the stage of using software strategies, the user should not interfere with the decisions made by the algorithmic strategy, but his task is to monitor the fulfillment of the planned results and the movement of the level of risk. In the case when software does not achieve desired results, it is necessary to correct the trading model and to return the strategy to the stage of optimization and efficiency testing. Automated trading software strictly adheres to the given strategies. In this way, the influence of human emotions on decision making is reduced and it is possible to overcome problems that may arise from neglect or lack of concentration (Ilić, 2010 a). 


\section{EMPIRICAL EVIDENCE RELATED TO AUTOMATED TRADING SYSTEMS}

Automated trading systems have created a number of new challenges and opportunities for both investors and their regulators. Since traders have been given the opportunity to better adapt their bids to new market information over the past few years, the share of high-frequency trading in the overall stock trading turnover has grown sharply, while market liquidity has been constantly improving (Jones, 2013, pp. 2). Diagram 1 shows the changing trend of high-frequency trading share in the overall volume of stock trading in the USA financial market.

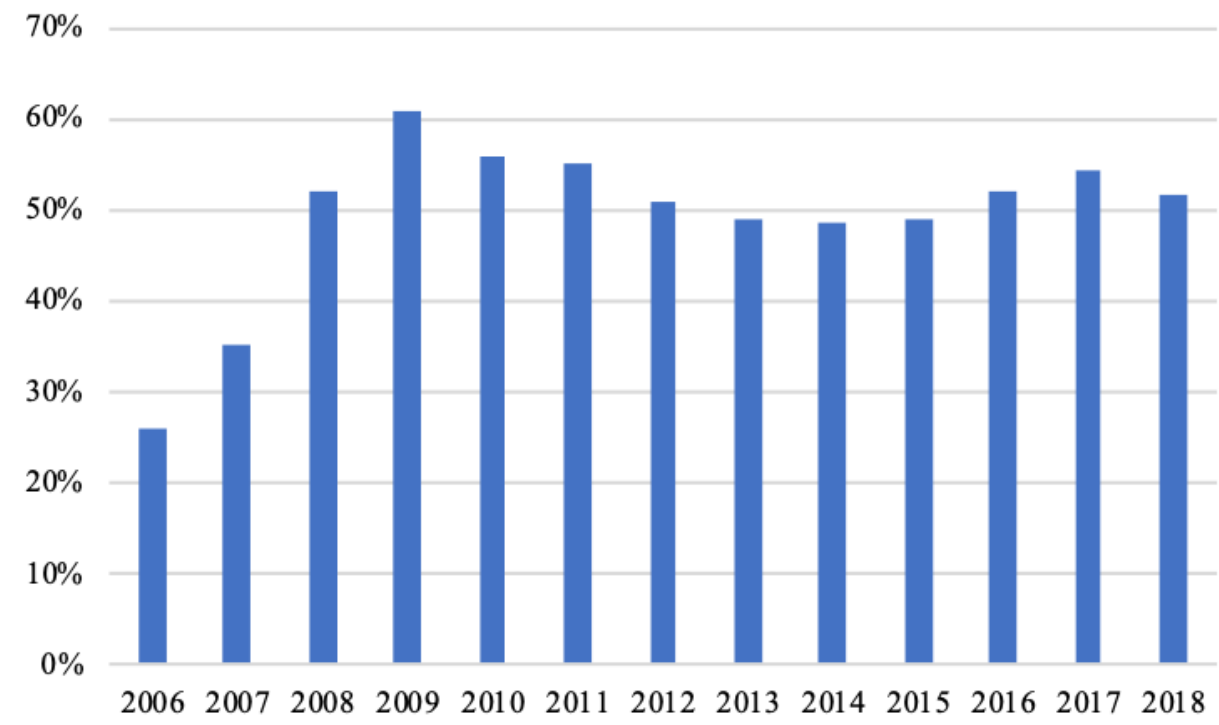

Diagram 1 Share of high-frequency trading in the overall stock trading turnover Source: https://www.theatlas.com/charts/HJ3PraH_7

During the observed period of time, a significant increase in the volume of automated trading was recorded. The share of high-frequency trading in the overall stock trading in the USA financial market increased from around $25 \%$ in 2006 to over $60 \%$ in 2009 . With the onset of the global economic crisis, a further trend of increasing the share of highfrequency trade stopped. From 2010 onwards, a steady decline and stagnation was noted in high-frequency trading. The share of these systems in post-crisis years was around $50 \%$. These data gain on significance when compared with the total annual number of trades presented in Table 1 . It can be seen that in the period 2004-2008, where the relative participation of high-frequency trading increased, a significant increase in the overall volume of trade was marked. In post-crisis years, the stagnation is followed by a fall in the total annual trade volume. The reasons for reducing high-frequency trading can be found in: a) a smaller amount of revenue and profit that was appropriated as the cost of technological infrastructure increased; b) the existence of intense competition within the industry and c) the growth of alternative trading platforms (Kaya, 2016). 
Table 1 Total annual trading volume in the USA financial market (in millions)

\begin{tabular}{cccccccc}
\hline Year & Trading & Year & Trading & Year & Trading & Year & Trading \\
\hline 2002 & 24,678 & 2007 & 48,957 & 2011 & 48,820 & 2015 & 40,866 \\
2003 & 20,405 & 2008 & 53,889 & 2012 & 45,390 & 2016 & 34,795 \\
2004 & 20,629 & 2009 & 51,001 & 2013 & 42,371 & 2017 & 34,844 \\
2005 & 38,372 & 2010 & 44,794 & 2014 & 40,944 & 2018 & 34,691 \\
\hline \multicolumn{7}{c}{ Source: https://www.itg.com/trading-volume/year/ } &
\end{tabular}

The application of automated trading systems to an increasing number of markets is owed to some of their key features. The speed of order execution as one of main features has been increasing significantly from year to year (Jones, 2013; Carrion, 2013; Dubey, Chauhan, \& Syamala, 2017). In addition to this, the key advantage is considered to be real-time decision making, along with the observation of a large number of parameters. Companies using high-frequency systems trade hundreds or thousands of times a day for their own account, where holding periods are measured in minutes or seconds. A recent research conducted by Indian authors (Dubey, Chauhan, \& Syamala, 2017) confirms that in the first five years of the automated trading system implementation in 2009, due to the high speed of transfer, the volume of trading in financial markets increased by $60 \%$.

The motive for high-frequency trading implementation is to generate revenue. However, traders who do not possess the technological infrastructure necessary to implement these systems face the high costs of introducing new equipment (Kearns, Kulesz and Nevmyvak, 2010, pp. 14). Riordan \& Storkenmaier (2011) observed technological changes on the German stock market in 2007, trying to find out whether this type of change has affected two important aspects of market quality - liquidity and price. The results confirmed that the time between order entering and verification was shortened by technological upgrade from about 50 to 10 milliseconds, whereby the reduced time provided greater liquidity on the market.

Most researches in the field of automated trading systems examine and confirm the existence of a positive impact of these systems on the quality of the market. Most often, they point to effects that contribute to increasing market efficiency - faster processing of information, timely decision-making, higher profits (Frino, Prodromou, Wang, Westerholm, \& Zheng, 2017) greater information efficiency in stock markets around the world (Das \& Kadapakkam, 2018), etc. However, the benefits of high-frequency systems should not be taken for granted. Though considered to be a positive aspect, speed might be unfavorable for other investors, which can lead to the emergence of adverse selection that reduces market quality (Jones, 2013, p. 1). On the other hand, Jovanovic \& Menkveld (2016) dispute these claims, stating that the implementation of high-frequency systems into financial markets reduces adverse selection by $23 \%$, with a $17 \%$ increase recorded in trade volume. Also, many regulatory barriers (each country has its own regulatory regime), as well as difficulties in identifying participants' identities, since most global stock exchanges function on the principle of voluntary disclosure of participants' identity, provide the possibility of placing anonymous orders (Comerton-Forde, Putninšs, \& Tang, 2011, pp. 3). The regulatory policy of the automated trading system of the Australian Stock Exchange (SEATS) stands out from others in that it enables direct participants to identify the traders' identity at all times (Berkman \& Koch, 2008, pp. 234). In this way, automated systems adopt one of the characteristics of the conventional trading method, i.e. significantly facilitated identification of a trader, which can reduce the risk of unfavorable selection when trading. 
In conditions of market disturbance and instability, there is an increase in the speed at which high-frequency systems exhaust the best prices for buying and selling leading to a change in trading volume, which may lead to a phase corresponding to some form of flash crash. This term refers to dramatic changes in prices on stock exchanges in a short period of time. One such event from the recent past was Flash Crash in 2010, in which Dow Jones dropped by almost 1,000 points within 10 minutes, which was followed by the recovery of most of the losses in just 30 seconds (Lakić, 2014, pp. 9). This event led to a fall in the price of a large number of shares in the market, some of which lost their entire value, while the value of others rose more than a factor of 1000 (Braun, Fiegen, Wagner, Krause, \& Guhr, 2018, pp. 2).

Flash Crash has raised a number of important issues related to the structure and stability of the USA financial markets. Many experts (Kirilenko, Kyle, Samadi, \& Tuzun, T., 2011; Akansu, 2017; Braun, Fiegen, Wagner, Krause, \& Guhr, 2018) attributed instability to excessive use of computers and high-frequency trading systems. However, the key question is whether these systems really made the market fragile and unstable. In fact, on Flash Crash day, the high-frequency trading system stabilized the prices at the very beginning, but the inflow of a large number of orders that overflowed the system disabled the liquidation of positions, which, due to the withdrawal of the high-frequency algorithms liquidity, further led to the acceleration of the subsequent crash. This is supported by the fact that almost two-thirds of the total trading volume on that day was submitted via high-frequency trading systems (Figure 2), and that in almost two minutes the critical fall of the Dow Jones index millions of shares were traded in each second (Lakic, 2014 , page 9). The largest number of canceled orders at these moments was recorded at high frequency traders (Figure 3).

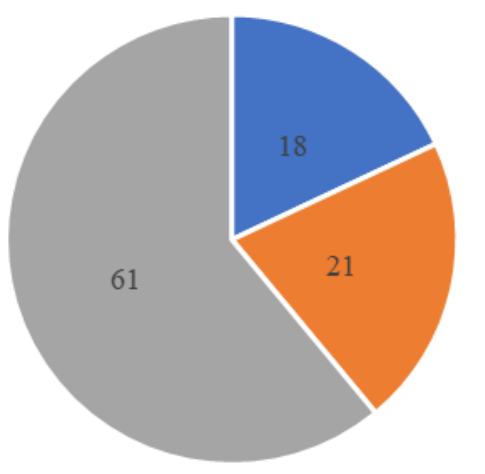

- Non-HFT

= Other HFT firms

- Investment bank - HFT

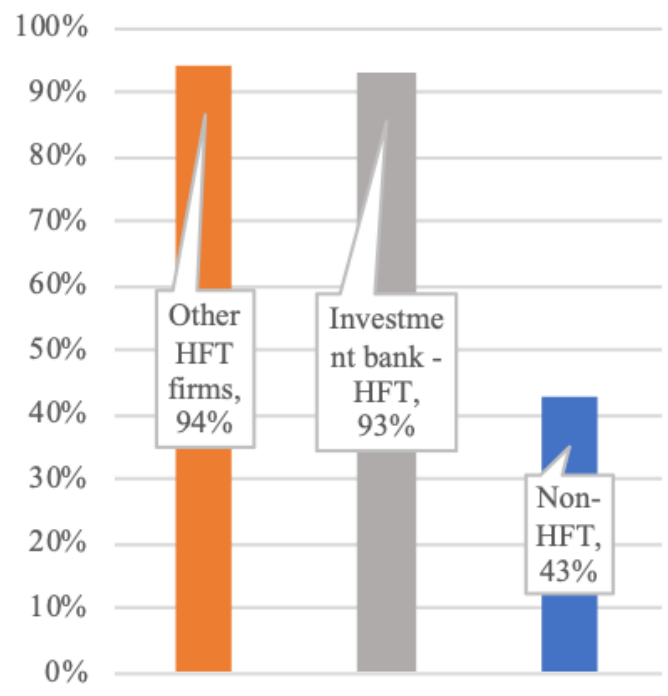

Fig. 2 Trading activity

Fig. 3 Cancellation ratio Source: Bellia, M., Christensen, K., Kolokolov, A., Pelizzon, L., \& Renò, R. (2018). High-Frequency Trading During Flash Crashes: Walk of Fame or Hall of Shame? 
The initiation of Facebook's initial public offering in May 2012 makes another example of market vulnerability caused by the use of high-frequency trading systems. The opening of Facebook on the stock market attracted a large number of investors, which was not supposed to be a problem for NASDAQ, because this over-the-counter market is characterized by the ability to process large amounts of orders. However, the huge demand for Facebook shares, which was placed using the orders of high-frequency system, made NASDAQ computers slow down. Instead of the usual 0.04 milliseconds to calculate the price, computers took almost a hundred times more, i.e. 5 milliseconds to carry out the same operation (Zook \& Grote, 2016, pp. 12). An unanticipated problem with NASDAQ's initial public offering system led to a 30-minute delay in opening Facebook positions, which is a serious lag in today's market environment characterized by hyperactivity (Kirilenko \& Lo, 2013, pp. 63). Despite the fact that after the initial delay, the trading of Facebook shares continued at a usual rate, short-term software problems on NASDAQ led to losses that cost investors and their brokerage houses tens of millions of dollars (Jones, 2013, pp. 41).

The rise of automated trading was followed by instabilities that made the financial markets more vulnerable than before. Technological concerns in the years following 2012 have led to the emergence of less dramatic market crashes, localized within the change of the value of one share. Most commonly, these market crashes are called ultrafast extreme events, since a significant increase or decrease in stock prices happens within milliseconds (Braun, Fiegen, Wagner, Krause, \& Guhr, 2018, pp. 1). There is a controversy in the attitudes held by experts on the reasons of mini flash crash emergence. Most often, the focus of their attention is still on high-frequency trading systems. However, market manipulation and unbalanced liquidity, on the one hand, and large orders, on the other, are also marked as possible triggers. Consequently, the regulators seek to gather all necessary information from the market in order to create adequate provisions in the field of automated trading systems, which will reduce the risk of endangering the integrity of the capital market.

\section{CONCLUSION}

The prospects for further development of financial markets and financial institutions rely heavily on future investments in information technology. One of the results of the previous investments in the development of technology is automated trading systems. At the very beginning of this paper, the theoretical analysis pointed out the superiority of these systems over conventional stock trading. Some of the benefits of these systems would be making decisions based on algorithms and executing orders in a virtual space between computers, with no need for immediate human intervention. The new era of trading enabled more efficient order execution, which ultimately resulted in improved characteristics of stock portfolio. Speed, real-time software decision making, automatic order execution and reduced transaction costs for traders have made global financial markets open to these systems. On the other hand, such a rapid expansion of automatic trading has seriously affected the stability of financial markets on several occasions. The evidence is provided by empirical research on the events such as Flash Crash, as well as the delay of the initial public offering of Facebook shares. In both cases, the risks 
associated with high-frequency trading such as inaccurate computer interpretation, lack of capacity, programming error or targeted manipulation seem to be the main instigators of market instability. The analysis shows that these events were one of the triggers for reducing high-frequency trading volume in the last few years. Altogether, although golden age is far behind, the conclusion is that risks can be avoided by introducing new appropriate measures of regulation and international standards, so that in the years to come, society can take advantage of the positive sides of these systems.

It should be noted that technological innovations are essential for the development and improvement of the market. In this regard, the positive influence that automated trading systems have on the quality of the market is indisputable and it is proven by earlier empirical researches. The contribution of these systems should not be called into question even if the circumstances when these systems can destabilize the market in the short term are taken into account. The market crashes pointed to the weaknesses of automated trading systems. Studying detected weaknesses should serve regulators, since further progress and evolution of automated trading systems necessarily require to be accompanied by appropriate regulatory measures.

Theoretical and empirical considerations presented in the paper contribute to the creation of new knowledge in the field of contemporary stock trading in global financial markets. By pointing out the key characteristics of automated trading systems, with an overview of the challenges of their implementation in practice, the paper has filled the existing gap in the research literature in Serbia. Having in mind the fact that the practical application of these systems was most often observed for the USA capital market, the recommendation for further research would be to include the financial markets of Europe and Asia into analysis.

\section{REFERENCES}

Akansu, N.A. (2017). The flash crash: a review. Journal of Capital Markets Studies, 1 (1), 89-100. doi:10.1108/JCMS-10-2017-001

Aldridge, I. (2009). High-Frequency Trading: A Practical Guide to Algorithmic Strategies and Trading Systems. Hoboken, New Jersey: John Wiley \& Sons, Inc.

Bellia, M., Christensen, K., Kolokolov, A., Pelizzon, L. \& Renò, R. (2018). High-Frequency Trading During Flash Crashes: Walk of Fame or Hall of Shame? SSRN Electronic Journal. doi:10.2139/ssrn.3190321

Berkman, H. \& Koch, P.D. (2008). Noise trading and the price formation process. Journal of Empirical Finance, 15 (2), 232-250. doi:10.1016/j.jempfin.2006.10.005

Braun, T., Fiegen, J., Wagner, D., Krause, S. \& Guhr, T. (2018). Impact and Recovery Process of Mini Flash Crashes: An Empirical Study. PLoS ONE, 13 (5). doi:10.1371/journal.pone.0196920

Carrion, A. (2013). Very fast money: High-frequency trading on the NASDAQ. Journal of Financial Markets, 16 (4), 680-711. doi:10.1016/j.finmar.2013.06.005

Comerton-Forde, C., Putniņš, T.J. \& Tang, K.M. (2011). Why Do Traders Choose to Trade Anonymously?. Journal of Financial and Quantitative Analysis, 46 (04), 1025-1049. doi:10.1017/s0022109011000214

Das, S. \& Kadapakkam, P.-R. (2018). Machine over Mind? Stock price clustering in the era of algorithmic trading. The North American Journal of Economics and Finance. doi:10.1016/j.najef.2018.08.014

Dugalić, V. \& Štimac, M. (2011). Osnove berzanskog poslovanja [Fundamentals of stock exchange operations]. Beograd: Stubovi culture.

Dubey, R. K., Chauhan, Y. \& Syamala, S. R. (2017). Evidence of algorithmic trading from Indian equity market: Interpreting the transaction velocity element of financialization. Research in International Business and Finance, 42, 31-38. doi:10.1016/j.ribaf.2017.05.014

Fong, S., Si, Y.-W. \& Tai, J. (2012). Trend following algorithms in automated derivatives market trading. Expert Systems with Applications, 39 (13), 11378-11390. doi:10.1016/j.eswa.2012.03.048 
Frino, A., Prodromou, T., Wang, G.H.K., Westerholm, P.J. \& Zheng, H. (2017). An empirical analysis of algorithmic trading around earnings announcements. Pacific-Basin Finance Journal, 45, 34-51. doi:10.1016/j.pacfin.2016.05.008

Gregoriou, G.N. (2015). The handbook of high frequency trading. Nederlands, Amsterdam: Academic Press/Elsevier

Ilić, V. (2010a). Metode za analizu finansijskih podataka i razvoj algoritamskih strategija za automatsko trgovanje [Methods for analyzing financial data and development of algorithmic strategies for automated trading]. Info $M, 34$ (9), 30-34.

Ilić, V. (2010b). The structure of software for automated trading on foreign exchange market. Retrieved from:

https://www.researchgate.net/publication/215530920_The_structure_of_software_for_automated_trading_ on_foreign_exchange_market/download Accessed on: $15^{\text {th }}$ December 2018.

Ilić, V. \& Brtka, V. (2011). Evaluation of algorithmic strategies for trading on foreign exchange market. Retrieved from: https://www.researchgate.net/publication/299287406_Evaluation_of_algorithmic_ strategies_for_trading_on_foreign_exchange_market/download Accessed on: $15^{\text {th }}$ December 2018.

Jakšić, M. (2016). Finansijsko tržište - instrumenti i institucije [Financial Market - Instruments and Institutions]. Kragujevac: Ekonomski fakultet Univerziteta u Kragujevcu.

Jones, C.M. (2013). What Do We Know About High-Frequency Trading?. SSRN Electronic Journal. doi: $10.2139 /$ ssrn.2236201

Jovanovic, B. \& Menkveld, A.J. (2016). Middlemen in Limit-Order Markets. SSRN Electronic Journal. doi: $10.2139 /$ ssrn. 1624329

Kanzaki, K. (1981) Immobilization of stock certificates: the position of the beneficial shareholder. Journal of Comparative Corporate Law and Securities Regulation, 3, 115-127.

Kaya, O. (2016). High-frequency trading: reaching the limits. Research Briefing Global financial markets. Frankfurt, Germany: Deutsche Bank Research

Kearns, M., Kulesza, A. \& Nevmyvaka, Y. (2010). Empirical Limitations on High Frequency Trading Profitability. The Journal of Trading Fall, 5 (4), 50-62. doi: 10.3905/jot.2010.5.4.050

Kirilenko, A.A., Kyle, A.S., Samadi, M. \& Tuzun, T. (2011). The Flash Crash: The Impact of High Frequency Trading on an Electronic Market. SSRN Electronic Journal. doi:10.2139/ssrn.1686004

Kirilenko, A.A., \& Lo, A.W. (2013). Moore's Law versus Murphy's Law: Algorithmic Trading and Its Discontents. Journal of Economic Perspectives, 27 (2), 51-72. doi:10.1257/jep.27.2.51

Kissell, R. (2014). The Science of Algorithmic Trading and Portfolio Management. San Diego, USA: Elsevier Science Publishing Co Inc.

Lakić, S. (2014). Magnituda visoko frkventnog trgovanja na tržištu akcija [The magnitude of high frequency trading on the stock market]. Economics \& Economy, 1 (3), 7-32.

MacKenzie, D., Beunza, D., Millo, Y. \& Pardo-Guerra, J.P. (2012). Drilling Through The Allegheny Mountains: Liquidity, Materiality and High-Frequency Trading. Journal of Cultural Economy, 5 (3), 279296. doi:10.1080/17530350.2012.674963

MacKie-Mason, J.K. \& Wellman, M.P. (2006). Automated Markets and Trading Agents. Chapter 28, Handbook of Computational Economics, 1381-1431. doi:10.1016/s1574-0021(05)02028-9

Miller, R.S. \& Shorter, G. (2016). High Frequency Trading: Overview of Recent Developments. Retrieved from: https://digital.library.unt.edu/ark:/67531/metadc847719/ Accessed on: $21^{\text {st }}$ December 2018.

Riordan, R. \& Storkenmaier, A. (2011). Latency, Liquidity and Price Discovery. SSRN Electronic Journal. doi:10.2139/ssrn.1247482

Sajter, D. (2013). Algoritamsko i visoko-frekventno trgovanje [Algorithmic and high-frequency trading]. Ekonomska misao i praksa, 22 (1), 321-336.

Stoll, R.H. (2006). Electonic Trading in Stock Markets. Journal of Economic Perspectives, 20 (1), $153-174$.

Venkataraman, K. (2001). Automated versus Floor Trading: An Analysis of Execution Costs on the Paris and New York Exchanges. Journal of Finance, 56 (4), 1445-1485.

Vuksanović, E. (2009). Elektronski sistemi plaćanja [Electronic payment systems]. Kragujevac: Ekonomski fakultet Univerziteta u Kragujevcu.

Zook, M. \& Grote, M.H. (2016). The microgeographies of global finance: High-frequency trading and the construction of information inequality. Environment and Planning A: Economy and Space, 49(1), 121140. doi:10.1177/0308518x16667298

https://www.theatlas.com/charts/HJ3PraH_7_(Accessed on: $23^{\text {th }}$ January 2019) 


\section{UTICAJ AUTOMATIZOVANIH TRGOVINSKIH SISTEMA NA STABILNOST FINANSIJSKIH TRŽIŠTA}

Razvoj informacionih tehnologija je suštinski promenio način funkcionisanja finansijskih tržišta. Automatizacija trgovinskih sistema na finansijskim tržištima predstavlja poslednji čin depersonalizacije aktivnosti koje su ranije obavljali trgovci. Razvojem algoritamskog trgovanja, računarima je potpuno prepušteno određivanje trenutka i načina izvršenja kupoprodajnih naloga. Računari i dalje ne donose autonomno odluke u pogledu izbora instrumenata koji će biti predmet trgovine, ili kriterijuma po kojima ce se trgovati. Oni implementiraju strategiju za koju se trgovac odlučio, birajući povoljan trenutak. Na ovaj način se smanjuje uticaj ljudskih emocija na donošenje odluka i omogućavaju prevazilaženje problema koji mogu nastati usled nepažnje ili nedostatka koncentracije. Visoko-frekventna trgovina omogućava izvođenje algoritamskih operacija velikom brzinom. Osnovni cilj rada je utvrđivanje prednosti i opasnosti koje produkuje algoritamsko trgovanje hartijama od vrednosti.

Ključne reči: automatizovani trgovinski sistemi, finansijska tržišta, visoko-frekventna trgovina 